\title{
MITO, DIVERSIDADE E INTOLERÂNCIA REFLEXÕES E APONTAMENTOS A PARTIR DE CASSIRER E HABERMAS
}

\author{
Rafael Rodrigues Garcia*
}

\begin{abstract}
Resumo: Este texto expõe algumas reflexões sobre os desafios que pautam as discussões políticas atuais numa sociedade globalizada. Baseados nas obras de Ernst Cassirer e Jürgen Habermas, exploramos a necessidade de coesão e respeito à diversidade que estes autores discutem, respectivamente, a partir das noções de forma simbólica e agir comunicativo. Partindo da crise da razão que marca o fim da modernidade, tratamos da reflexão sobre os limites desse modelo de razão e o problema da unidade do conhecimento-de-si, que tem como um de seus efeitos a revitalização do pensamento mítico na esfera política. Em seguida tratamos de reflexões sobre o ressurgimento da influência da religião na esfera política, de sua legitimidade e dos desafios que isso representa para a convivência democrática tolerante. Por fim, faremos apontamentos sobre questões hoje em pauta nos debates políticos sobre tolerância e diversidade.
\end{abstract}

Palavras-chave: pensamento mítico; intolerância; diversidade; Cassirer; Habermas

\begin{abstract}
This paper shows some reflections concerning the challenges in the political discussions in the globalized society. Based in the works of Ernst Cassirer and Jürgen Habermas we inquire into the necessity of cohesion and respect to the diversity, discussed by these autors through the notions of simbolic form and communicative action, respectively. Beginning with the crises of reason at the end of modernity, we deal with the limits of this model of reason and the issue of the unity of selfknowledge, which has amongst its effects the revitalization of the mythic thought in the political sphere. After that we deal with considerations about the resurgence of the religion's influence in policy, its legitimacy and challenges to a democratic tolerant acquaintance. At last we present some remarks about issues concerning intolerance and diversity.
\end{abstract}

Keywords: mythical thought; intolerance; diversity; Cassirer; Habermas.

\footnotetext{
* Doutorando em Filosofia pela Universidade de São Paulo - São Paulo, SP, Brasil. Bolsista Capes. E-mail: <www.raroga@gmail.com>.
} 
$|216|$

Mito, Diversidade e Intolerância...

\section{Introdução}

Um ponto de convergência entre Cassirer e Habermas é a necessidade de repensar o conceito de razão que deve ser tomado como centro de articulação num mundo multicultural. Cassirer vive a crise da razão que emerge no limiar do século XX; Habermas reflete sobre ela na segunda metade do século. Ambos repensam a razão prática em termos que a impeçam de se identificar com a razão unificadora, identificadora e adversa, portanto, à diversidade. Cassirer recorre ao símbolo; Habermas, ao agir comunicativo. Com este, Habermas trata das ações orientadas para o entendimento mútuo, que pressupõe uma diferença significante entre os interlocutores, mas que ao mesmo tempo possa ser referida a um denominador comum, ou seja, uma atividade racional que não se orienta instrumentalmente em relação ao mundo e, por isso, fazse capaz de exercer a necessária mediação entre os interlocutores. Este agir comunicativo pode ser aproximado da noção cassireriana de forma simbólica que, em linhas gerais, substitui o conceito estreito de razão derivada do modelo de ciência natural da modernidade pelo símbolo, mais adequado à compreensão dos fenômenos culturais.

Importante aqui é mostrar a centralidade da noção habermasiana para a construção de um modelo de democracia que não se pauta pela subsunção de uma das partes da relação de comunicação à outra, mas pela constatação da existência de uma diversidade concreta que deve ser considerada sem aniquilar uma das partes e sem, de outro lado, cessar a interação, do mesmo modo que faz a teoria das formas simbólicas em relação a cada forma em particular. A questão de fundo que aqui trazemos sob o pretexto da crise da razão é também aquela que nos leva a pensar nos efeitos nefastos de uma razão concebida estreitamente ou reduzida a instrumento. Dessa estreiteza (cientificista/tecnicista) temos uma postura que desqualifica determinadas manifestações do espírito ao passo que elege outras como modelo. Daqui emergem respostas igualmente intolerantes, como aquelas que as religiões fundamentalistas que tentam desqualificar a razão por completo 
e, sem perceber, instauram um clima mítico. De sua redução a instrumento, perdemos o contato com o mundo da ética e do direito, bem como com o da intersubjetividade em sentido próprio. Os efeitos disso são a fragmentação social e decadência da esfera pública e, dela, a intolerância.

\section{Crise da razão}

A obra de Cassirer remonta ao neokantismo da Escola de Marburgo, do qual se afasta ao longo de sua trajetória intelectual. A marca desse afastamento é o próprio projeto da Filosofia das formas simbólicas, que expressa a limitação do método transcendental da Escola de Marburgo tal qual concebido por Hermann Cohen. Para Cassirer, não era mais possível insistir no conceito de razão que articulava sob si a totalidade dos fenômenos e lhes imprimia sentido e valor. Essa razão, centralizadora e marcada fortemente pela influência da atividade científico-matemática, não é capaz de dar conta adequadamente de todos os fenômenos da existência humana em sua tendência e dinâmica específicas e não pode senão submetê-los ao seu próprio crivo. O paradigma para as ciências humanas proposto pela Escola de Marburgo, ainda sob a batuta de Cohen era ainda por demais logicista - lembremos que este grupo também era conhecido como a escola do Idealismo Lógico. Cassirer, em sua juventude, procura levar o paradigma da Escola até suas últimas conseqüências, procurando adequar suas premissas aos então recentes avanços da lógica empreendidos por Frege e Russell, o que é feito na obra publicada em 1910, Conceito de substância e conceito de função (CASSIRER, 1910: cap. I). Anos mais tarde, no texto de abertura do primeiro volume da Filosofia das formas simbólicas, Cassirer alude a essa questão, apontando a necessidade que sentiu de mudar os horizontes de sua investigação:

O presente texto constitui o primeiro volume de uma obra cujos esboços iniciais remontam às investigações que se encontram resumidas no meu livro Conceito de Substância e Conceito de Função. Estas pesquisas 
diziam respeito, principalmente, à estrutura do pensamento no campo da matemática e das ciências naturais. Ao tentar aplicar o resultado de minhas análises aos problemas inerentes às ciências humanas, fui constatando gradualmente que a teoria geral do conhecimento, na sua concepção tradicional e com as suas limitações, é insuficiente para um embasamento metodológico das ciências do espírito. Para que o objetivo fosse alcançado, foi necessária uma ampliação substancial do programa epistemológico (CASSIRER, 1923: 1).

E é aqui que passamos, de fato, à especificidade do projeto das formas simbólicas e ao seu valor como reflexão sobre a crise da razão. Essa crise, que é a marca maior do fim da modernidade, é a crise da legitimidade da razão que decorre da própria exploração da razão empreendida pela modernidade. As pretensões epistemológicas e todas as demais que dela dependiam vieram abaixo, na esteira da ruína da metafísica, a primeira a cair.

$\mathrm{N}^{\prime} \mathrm{O}$ discurso filosófico da modernidade Habermas expõe o desenvolvimento da racionalidade moderna que posteriormente levaria à crise (HABERMAS, 1985: caps. IV-VI). Há um ponto que devemos aqui destacar: o processo de esclarecimento trouxe em seu bojo de um lado a fragmentação da razão no processo de autonomização que, depois de se livrar das amarras dos encantamentos míticos e miméticos, é interiorizada pela razão, já convertida e degradada em razão instrumental; e, por outro lado, esse mesmo processo de desencantamento alimentou secretamente sua força antagônica: o mito, arcabouço e repositório da coesão social. No primeiro caso, parece hoje haver unanimidade entre aqueles que estudam a modernidade sobre o fato de que sua própria lógica interna levou-a ao colapso da fragmentação que, no limite, conduziria à incomensurabilidade e, destarte, à cessação da possibilidade de diálogo entre domínios especializados distintos - paradoxalmente ao que se esperaria da razão como logos. Ao mesmo tempo, a redução da racionalidade à técnica embota sua 
capacidade crítica, além de dissociá-la das suas incumbências nãoutilitárias, mormente éticas e estéticas.

\begin{abstract}
Com a assimilação naturalista entre pretensões de validade e pretensões de poder, com a destruição das faculdades críticas, concorre o aperfeiçoamento das culturas de especialistas, nas quais uma esfera articulada de validade proporciona uma especificidade às pretensões de verdade proposicional, de justeza normativa e de autenticidade, embora também uma vida própria esotérica, ameaçada, por sua vez, pela dissociação com a práxis comunicativa do cotidiano (HABERMAS, 1985: 162).
\end{abstract}

Os efeitos se fazem sentir no âmbito da razão prática, que não logra êxito na empreitada de substituir o poder unificador da religião. $\mathrm{O}$ anseio romântico pela nova mitologia é prova da percepção que já se tinha da fragmentação que eclodiu na virada do século XX. Nem estetização nietzscheana da filosofia e da ciência nem a ruptura dionisíaca do principium individuationis conseguiram alcançar o horizonte fora da razão com o qual conseguiria desmascarar toda a ideologia sem recair, à revelia, em outra. Ao fim e ao cabo, Nietzsche contribui para a destruição das faculdades críticas e, no afã de se desvencilhar da modernidade e superar a metafísica, põe em cena uma nova heteronomia. Heidegger, por seu turno, dissolve o que sobrava da razão em favor de um "pensamento essencial", "mais rigoroso do que o conceitual" (1967: 353 apud HABERMAS, 1985: 194), que no intuito de resgatar o Ser coloca o sujeito numa posição de sujeição vazia. "A dimensão da inocultabilidade que precede a verdade proposicional, passa do projeto consciencioso do indivíduo, que cuida de sua existência, para um destino do Ser, anônimo, que exige submissão, que é contingente e que prejulga o curso da história concreta" (HABERMAS, 1985: 218).

A primazia da (auto-)reflexão, marca do sujeito moderno, é substituída na guinada hermenêutica existencial, e em seu lugar aparece a dimensão do mítico: “O acontecer do Ser pode ser apenas 
experimentado com devoção e exposto em narrativas, não podendo ser alcançado nem explicado com argumentos" (HABERMAS, 1985: 215). Lembramos aqui que o significado primeiro de mythos é narração e remete à narrativa e ao acesso imediato, ou anterior às mediações da reflexão (razão discursiva). Heidegger busca resgatar o momento anterior ao estabelecimento da metafísica que cindiu o Ser do ente e pretende encontrar esse momento na palavra ressacralizada do poeta: "o sagrado, na qualidade do qual o Ser há de ser expresso na palavra do poeta, é considerado, tal como na metafísica, como absolutamente imediato" (HABERMAS, 1985: 215). No fim, a própria subjetividade é obliterada na noção de destino, num desenvolvimento cujo ápice é a identificação com o nazismo.

\section{O mito na política}

Para Cassirer, a perda da unidade do conhecimento, que foi obliterado à medida que as ciências se especializavam em esferas autônomas de valoração, tem por efeito derradeiro e mais pernicioso a crise do conhecimento-de-si do homem (CASSIRER, 1944: cap. 1). A crise da ciência é internalizada no próprio homem: cada ramo específico da ciência dava por si explicações com pretensões universalistas de resolver e desvendar a questão do homem, muito embora as respostas dadas por cada uma dessas ciências só fizessem reduzir os fenômenos a um único ponto de vista e, quando vistas em conjunto, confrontadas entre si, se mostravam incapazes de conciliação.

Nietzsche proclama a vontade de potência, Freud assinala o instinto sexual, Marx entroniza o instinto econômico. Cada teoria torna-se um leito de Procusto no qual os fatos empíricos são esticados para amoldarse a um padrão preconcebido. [...] Teólogos, cientistas, políticos, sociólogos, biólogos, psicólogos, etnólogos e economistas, cada qual abordou o problema a partir de seu ponto de vista. Combinar ou unificar todos esses 
aspectos e perspectivas particulares era impossível. E nem em cada um dos campos especiais havia um princípio científico de aceitação geral (CASSIRER, 1944: 41-2).

Chega-se aqui ao marco zero da fragmentação que caracterizará o final da modernidade. Toda a exposição histórica que Cassirer faz no capítulo inicial do Ensaio Sobre o Homem acerca do problema do autoconhecimento tem por fim a crise como a fragmentação do próprio homem, que não tem mais uma "orientação geral", como teve no mito, na metafísica, na religião e na ciência moderna. ${ }^{1}$ A crise que se iniciou com as ciências tornou-se então uma crise da própria racionalidade, da qual a racionalidade moderna é só um exemplo.

A tarefa da filosofia, nessa circunstância, seria a de combater a fragmentação que saiu da racionalidade e abalou toda a cultura, integrando cada uma das disposições específicas do espírito humano numa "unidade conceitual" mais ampla. Essa é a principal razão que faz Cassirer propor sua obra como uma "crítica da cultura", caudatária, para o autor, da filosofia crítica de Kant. "A crítica da razão transforma-se, assim, em crítica da cultura" (CASSIRER, 1923: 22). É só a partir de um entendimento da dinâmica cultural, tomada como a totalidade das produções do espírito em suas tendências básicas de objetivação, que é possível manter a unidade ameaçada do próprio homem, e só nessa totalidade poderá o homem alcançar finalmente o conhecimento de si.

\footnotetext{
${ }^{1}$ Nesse ponto, o diagnóstico de Habermas não difere do de Cassirer. Para ele, as separações e autonomizações das esferas da vida do indivíduo "abrem o caminho à emancipação de dependências muito antigas, [mas] serão experimentadas simultaneamente como abstração, como alienação em relação à totalidade de um contexto de vida ético. No passado, a religião foi o selo inviolável posto sobre essa totalidade. Esse selo, não por acaso, rompeu-se" (HABERMAS, 2000: 122).
} 
$\mid 222$ |

Mito, Diversidade e Intolerância...

Tomada como um todo, a cultura humana pode ser descrita como o processo da progressiva autolibertação do homem. A linguagem, a arte, a religião e a ciência são várias fases desse processo. Em todas elas o homem descobre e experimenta um novo poder o poder de construir um mundo só dele, um mundo "ideal". (CASSIRER, 1944: 371)

Para resolver o problema da crise, Cassirer propõe uma "ampliação do programa epistemológico", que é feita pelo deslocamento da categoria de razão para categoria de símbolo como o eixo de articulação dos fenômenos. Para o filósofo, o homem não é apenas um animal racional, mas um animal simbólico (CASSIRER, 1944: 50). E argumenta:

A racionalidade é de fato um traço inerente a todas as atividades humanas. A própria mitologia não é uma massa grosseira de superstições ou ilusões crassas. Não é meramente caótica, pois possui uma forma sistemática ou conceitual. Mas, por outro lado, seria impossível caracterizar a estrutura do mito como racional. A linguagem foi com freqüência identificada à razão, ou à própria fonte da razão. Mas é fácil perceber que essa definição não consegue cobrir todo o campo. E uma pars pro toto; oferece-nos uma parte pelo todo. Isso porque, lado a lado com a linguagem conceitual, existe uma linguagem emocional; lado a lado com a linguagem científica ou lógica, existe uma linguagem da imaginação poética. (...) E até mesmo uma religião 'nos limites da razão pura', tal como concebida por Kant, não passa de mera abstração. Transmite apenas a forma ideal, a sombra, do que é uma vida religiosa genuína e concreta (CASSIRER, 1944: 49).

Em vez de apostar na articulação das formas simbólicas em torno do conceito de razão, tal como se pretendeu fazer a partir do diagnóstico de autonomização das esferas ao longo da modernidade, Cassirer insiste na diferença dessas formas simbólicas entre si. É preciso perscrutá-las em sua tendência 
específica - assim, Cassirer traz à baila a abordagem tautegórica para o mito, em referência direta a Schelling, e a aplica às demais formas simbólicas: cada forma simbólica é uma explicação totalizante dos fenômenos; elas os articulam e, em sua ação, criam mundos. "Sob uma forma simbólica", diz o filósofo, "deve ser entendida toda a energia do espírito através da qual um conteúdo mental de significado é conectado a um signo concreto, sensório e adere internamente a ele" (CASSIRER, 1923b: 79, grifo nosso, tradução nossa).

Fica evidente aqui que a noção de símbolo é mais adequada, dada sua flexibilidade e fluidez, para dar conta daquilo que anteriormente se atribuía à razão. Mas a principal vantagem obtida com essa rearticulação do caráter básico da atividade humana é poder manter um centro de articulação que dê unidade às manifestações do espírito humano e que garanta a cidadania da diversidade dessas manifestações. Cassirer pretende unir-em-torno do símbolo tudo aquilo que era subsumido à razão. E essa é a grande diferença: a razão opera em função da identificação, do identificar, e, portanto, subsume a totalidade a partir de si, ao passo que o símbolo congrega em torno de si e não impinge aos fenômenos uma forma em particular. A razão unifica; o símbolo diversifica. Ele é dotado da versatilidade que falta à rigidez da razão científica. Por conta disso, não se deve esperar dele a univocidade que esta tem como parâmetro. A filosofia da cultura deverá ser a investigação da diversidade cultural; "apreciamos a policromia e a polifonia da natureza do homem" (CASSIRER, 1944: 361).

Tal unidade [a partir do símbolo] não pressupõe uma homogeneidade dos vários elementos de que consiste. Nem tampouco simplesmente admite, ou sequer pede, uma multiplicidade e multiformidade de suas partes constituintes. Trata-se de uma unidade dialética, uma coexistência de contrários. (CASSIRER, 1944: 362)

Somente a partir do símbolo é possível tirar o homem do leito de Procusto. 
As formas simbólicas se desenvolvem a partir do solo comum e indiferenciado do mito, que é a primeira forma de relação da consciência com o mundo. A primeira grande cisão na consciência é a que separa o indivíduo do mundo, ou da unidade da vida (CASSIRER, 1925): ela ocorre ao mesmo tempo para fora e para dentro do indivíduo, que apreende os limites do não-Eu e, por conseguinte, delimita o Eu em relação ao mundo que se faz objetivo. Esse é um processo gradual, que tem como um dos estágios intermediários a identificação do Eu com a tribo (no caso das sociedades totêmicas, por exemplo) e com os ancestrais. ${ }^{2}$ A individuação com as características da modernidade é um fenômeno recente, segundo Cassirer, que aqui fala em perspectiva antropológica. É ao solo mítico que o filósofo remete a coesão social, baseado, sobretudo, em Durkheim e Malinowski (Cf. CASSIRER, 1944 e 1925).

As demais formas surgem em diferenciação e oposição à consciência mítica por um processo dialético semelhante ao da fenomenologia de Hegel, com duas diferenças centrais: 1. a primeira figura do espírito não é a consciência sensível, mas o mito, que corresponde a um degrau anterior na escada hegeliana. 2. a dialética do espírito de Cassirer não tende à forma da lógica, na qual se encontra o espírito absoluto e, por assim dizer, o fim da história. Manter a independência das formas simbólicas redunda em manter a dinâmica, o movimento, e isso coloca a cultura numa perspectiva distinta daquela imaginada para a civilização pela modernidade. Os ideais de paz perpétua e de espírito absoluto, grosso modo, são caudatários de uma idéia de razão que supõe haver um estado de perfeição, análogo à noção de verdade lógica. No campo da razão prática, é a justificativa da submissão das formas simbólicas à forma lógica (racional, em sentido estreito).

A tarefa da crítica da cultura é dar conta da dinâmica e dos conflitos provenientes da interação das formas simbólicas. Do ponto de vista da totalidade, a cultura forma um sistema harmônico, orgânico. Trata-se de uma harmonia dinâmica, não

\footnotetext{
${ }^{2}$ Ver especialmente CASSIRER, 1925: partes II e III.
} 
estática. O surgimento de cada forma não figura um confronto pacífico, mas "um choque de poderes espirituais conflitantes." (CASSIRER, 1944: 21) No detalhe, é possível notar a concorrência entre as formas simbólicas por hegemonia, da mesma forma que no interior de cada forma há um desenvolvimento dialético entre reprodução e criação; entre tradição e inovação.

Esse dualismo é encontrado em todos os domínios da vida cultural. O que varia é a proporção dos fatores opostos. Ora um fator, ora outro, parece preponderar. Essa preponderância determina em alto grau o caráter das formas isoladas e confere a cada uma delas a sua fisionomia particular. (CASSIRER, 1944: 365)

Nesse quadro, o mito e formas primitivas de religiosidade tangenciam o pólo estável da reprodução e da tradição; a linguagem, a arte e as formas mais maduras de religião se equilibram entre um extremo e outro, com ocasionais propensões a um lado ou outro; a ciência é a que mais se aparta do pólo da tradição e da reprodução. Vale notar como o processo de autolibertação é também um processo que leva da tradição, esta que priva e tolhe qualquer manifestação de liberdade individual, ao campo da criação, da construção simbólica do mundo - e nos abre caminho para a civilização. (CASSIRER, 1944: 50)

Tendo como pano de fundo as convulsões pelas quais passava a república de Weimar, o debate entre Cassirer e Heidegger em 1929 representou a vitória do misticismo irracionalista heideggeriano sobre a posição conciliadora e moderada de Cassirer. O debate é sintomático da situação vivida pela Alemanha do fim dos anos 1920 e é um bom exemplo da dilaceração que acometia o homem. Anos mais tarde, n'O mito do Estado, Cassirer se deterá em considerar o clima geral do período da República de Weimar, incluindo aí o papel desempenhado por Heidegger, em que o mito sobrepujou a razão. A argumentação de Cassirer consiste numa detalhada explicação da criação e do desenvolvimento dos mitos políticos do século XX, com atenção especial à raça totalitária, de Gobineau, ao culto do herói, de Carlyle e a uma interpretação da teoria do Estado de 
Hegel (CASSIRER, 1946: caps. XV-XVII). Essas tendências, que têm suas raízes no século XIX, são apropriadas pela máquina nazista de modo a instaurar um ambiente verdadeiramente mitificado: os comportamentos são ritualizados mesmo para as atividades mais corriqueiras; a individualidade é obliterada e pouco a pouco a noção de responsabilidade é delida. A crise econômica somada ao orgulho ferido pela humilhação imposta no tratado que se seguiu ao fim da primeira guerra são o estopim que o mito precisava para conseguir irromper das trevas e novamente dominar a consciência. $\mathrm{O}$ inimigo que a razão julgava derrotado e exilado reaparece vigorosamente como um subproduto da crise da razão; assim como afirma a Dialética do esclarecimento (que Habermas subscreve), o mito é gestado no seio da racionalidade moderna. $\mathrm{O}$ regime nazista se vale do ambiente que encontra e o potencializa, apelando ao arcabouço emocional e não-racionalizado da cultura, de modo a deliberadamente engendrar e difundir o que Cassirer define como mitos políticos, noção com a qual marca a diferença entre a forma propriamente mítica de pensamento, aos quais não se pode atribuir autor nem deliberação técnica, e os mitos criados para viabilizar algum fim - no caso em questão, a coesão social sob a figura do herói, o líder, que poderia levar o povo alemão, ariano, a alcançar o que já estava traçado como seu destino desde sua origem e, dessa forma, resolver definitivamente os problemas que tal povo enfrentava. Assim, o povo, sob a tutela do líder, foi unido enquanto raça e enquanto partes de uma mesma origem e um mesmo destino - Carlyle; Gobineau; Hegel.

Se tentarmos decompor os mitos políticos contemporâneos nos seus elementos, descobriremos que eles não contêm qualquer aspecto inteiramente novo. Todos os seus elementos já eram bem conhecidos. A teoria de Carlyle do culto do herói e a tese de Gobineau sobre a fundamental diversidade intelectual e moral das raças humanas tinham sido discutidas frequentemente. Mas todas essas discussões permaneciam num plano meramente acadêmico. Para transformar as velhas ideias em fortes e poderosas 
armas políticas era necessário qualquer coisa mais. Tinham de acomodar-se ao entendimento de um público diferente. Para esse fim era necessário um novo instrumento - não somente um instrumento de pensamento, mas também de ação. Tinha de ser desenvolvida uma nova técnica. Foi esse o último e decisivo fator. Para utilizar linguagem científica, podemos dizer que essa técnica teve um efeito catalítico. Acelerou todas as reações e deu-lhes o seu pleno efeito. Embora o solo viesse sendo preparado desde há muito para o mito do século $X X$, não teria produzido o seu fruto sem a utilização hábil da nova ferramenta técnica. (CASSIRER, 1946: 321)

Uma das conseqüências do predomínio da forma mítica na política é a potencialização de uma de suas qualidades mais características: a intolerância. O pensamento mítico, impermeável a argumentos e irredutível em sua posição, é talvez, e por si só, a força com potencial mais devastador dentre aquelas que compõem o conjunto da cultura. Tendo em mente que ele é a figura mais próxima da reprodução e da tradição (mais avessa à liberdade do espírito), percebemos que o seu ressurgimento como eixo de articulação numa sociedade complexa só pode acontecer a partir de uma espécie de interversão e hipóstase da racionalidade (em sentido amplo) que a faz abdicar como que instantaneamente da liberdade que a caracteriza em favor da segurança trazida pelo grilhão do mito. Cassirer não é exatamente otimista em relação às perspectivas da política em relação a isso. Nos parágrafos finais d'O mito do Estado, ele diz:

Está para além do poder da filosofia destruir os mitos políticos. Em certo sentido, o mito é invulnerável. É impenetrável aos argumentos racionais; não pode ser refutado por silogismos. Mas a filosofia pode prestar-nos outro serviço importante. Pode fazer-nos compreender o adversário. (CASSIRER, 1946: 341. Grifo nosso). 
Talvez a assertiva de Cassirer não seja de todo pessimista. Para bem entendermos o que aqui está em jogo, basta considerar que a destruição dos mitos equivaleria a garantir a perpetuação de um estado de liberdade. Ora, estaríamos aqui reiterando a expectativa iluminista de um momento de pleno esclarecimento, uma vez que liberdade, autonomia e esclarecimento são termos indissociáveis. O que Cassirer diz aqui é apenas: não há um momento tal de plena vitória da razão sobre as forças míticas, seu oposto. Mas se a vitória está fora de questão, nem por isso estamos fadados à submissão ao poder do mito. O filósofo abre assim um caminho, característico da filosofia das formas simbólicas e, destarte, incumbência de uma filosofia crítica da cultura: compreensão.

Infelizmente não podemos contar com os desdobramentos dessa ideia feitos pelo próprio filósofo, que faleceu quando $O$ mito do Estado estava em seus estágios finais de redação. Contudo, levando em conta o que foi aqui exposto, depreendemos que estes desdobramentos conteriam a defesa de um modelo político que se pautasse pela viabilização dessa compreensão entre formas diversas da cultura humana. Algo que apenas pode ser garantido por um sistema democrático. Podemos ainda dizer, en passent, que a atitude de compreensão do filósofo se articula com duas questões centrais: a necessidade de tornar possível o diálogo, por um lado, e a necessidade de evitar a intolerância, por outro. De certa forma, ambas as questões são interdependentes e se entrelaçam na problemática da obra de Habermas, quando este articula sua concepção de democracia dando primazia à noção de agir comunicativo.

\section{A religião na esfera pública}

A guinada de Habermas em direção ao debate sobre a influência das religiões nos sistemas políticos modernos foi, para muitos, surpreendente, pois que representa uma mudança profunda no paradigma da teoria política (em boa medida 
weberiano) que vê o progresso social e a instituição democrática moderna como um processo atrelado à laicização do Estado e a democracia moderna como um produto da separação entre igreja e Estado, associado a ideais libertários iluministas. Assim, admitir que tal processo histórico não represente o caminho "natural" do desenvolvimento social, mas, contrariamente, talvez seja apenas "um caminho que foge à normalidade" (HABERMAS, 2005: 131), é algo de fato inesperado. Contudo, o aumento da influência política das religiões é um fato - e talvez o mais apropriado que nos leva a refletir sobre os limites da própria democracia e de sua capacidade de dar lugar à pluralidade e ao diverso. Antes, porém, de tratar propriamente da questão do papel da religião nas sociedades contemporâneas, cabe um breve excurso sobre a noção de agir comunicativo, tal qual desenvolvida por Habermas.

Esta noção aparece na obra homônima Teoria do agir comunicativo. Vale ressaltar que a obra em questão tem uma temática que, partindo de outra perspectiva histórica, pode ser aproximada da filosofia das formas simbólicas, já esboçada aqui: a obra faz um apanhado do desenvolvimento da racionalidade moderna que culmina na redução desta à razão instrumental. Nessa perspectiva, a razão comunicativa surge da necessidade de recuperar a dimensão da razão que possibilita o entendimento mútuo, livre de dominação. Com essa ampliação de perspectiva Habermas não foge apenas do modelo weberiano. Simultaneamente, ele consegue rearticular o diagnóstico pessimista de Horkheimer e Adorno, segundo os quais a capacidade crítica foi esvaziada na medida em que a racionalidade recrudesce ao mero serviço da autoconservação. Diz Habermas:

Na modernidade cultural, a razão é despida definitivamente de sua pretensão de validade e assimilada ao puro poder. A capacidade crítica de tomar posição ante algo com um 'sim' ou um 'não', de distinguir entre enunciados válidos e inválidos é iludida, na medida em que poder e pretensões de validade entram em uma turva fusão. (HABERMAS, 1985: 161). 
$|230|$

Mito, Diversidade e Intolerância...

Dessa fusão brotam os problemas epistemológicos, já mencionados, que invadem os outros domínios da atividade humana ou, no léxico habermasiano, o mundo da vida, noção cara a Habermas para dar conta das suposições de fundo nãoproblematizadas e partilhadas intersubjetivamente.

Uma das grandes vantagens da noção de agir comunicativo é sua capacidade de congregar diversos discursos que concorrem no mundo da vida, além de, na mesma medida, problematizar seu ponto de partida e validade; em suma, criticá-los, mas de uma forma diferente daquela empreendida pela primeira geração da teoria crítica, pois que realizada do ponto de vista da filosofia da linguagem em vez da filosofia da consciência. Enquanto nesta última, reinante na filosofia (e na política) moderna, a dimensão da solidariedade é obliterada no renitente solipsismo cartesiano que não cessa de voltar à baila e que, do ponto de vista da razão prática, conduz à falácia do "atomismo social", a razão comunicativa se apóia justamente na intersubjetividade, anterior à própria percepção de interioridade/individualidade, e, desse modo, parte do pressuposto da ação coletiva produtora de significado. Bem entendida, a ação comunicativa dá acesso apenas indireto ao mundo objetivo, mas permite o entendimento direto e, por este motivo, é imprescindível para a convivência e para o exercício político democrático ${ }^{3}$, este que deve se basear na deliberação. Com efeito, a própria definição de esfera pública em Habermas tem como eixo central a noção de razão comunicativa.

De volta, pois, ao problema do inesperado aumento da religião na política, que ocorre também em democracias consolidadas, ou seja, em sociedades nas quais a separação entre Estado e igreja já não é mais ponto de problematização, além daquelas que, ainda sem tal separação, parecem caminhar rumo ao desenvolvimento social com matiz democrático.

3 Com efeito, poderíamos mesmo concordar aqui com Aristóteles, salvaguardadas as diferenças conceituais aqui e lá, quando ele afirma que só a democracia é, com o sentido próprio do termo, política. 
É importante dizer que esse ressurgimento da religião no meio político não tem uma única e mesma causa em todas as situações em que acontece. Se é verdade que, "desde os dias da Revolução Francesa, as forças de um tradicionalismo religioso que se auto-interpreta como contra-revolucionário" (HABERMAS, 2005: 130) são conhecidas, é também verdade que, mundo afora, o ressurgimento da religião no seio político aparece como resistência aos valores ocidentais em algumas sociedades do oriente médio, por exemplo, mas também como resgate tradicionalista dentro de determinadas configurações políticas ocidentais, ou mesmo como movimentos pioneiros de luta pelos direitos humanos. No Brasil, por exemplo, a religião vem aparecendo no debate político tanto com temas tradicionalistas e conservadores, como na luta pela manutenção da proibição do aborto e da união homoafetiva, quanto em lutas de bandeiras de esquerda, como a reforma agrária.

Entretanto, o que está aqui em questão é a capacidade que tem a religião, ou melhor, os cidadãos religiosos, de participarem efetivamente da vida política democrática. A questão fica clara quando lembramos que é uma característica marcante de toda religião apresentar-se como a instância de legitimação por excelência para todos os âmbitos da vida do fiel, valendo-se de justificativas de cunho metafísico. Do ponto de vista de uma democracia deliberativa, que supõe conciliação de interesses e, ainda mais importante, dado que estamos num ambiente pósmetafísico em cuja dinâmica os valores são legitimados pela própria concordância em relação a eles, o que se questiona é a capacidade de um cidadão religioso de se adequar a resoluções conflitantes com as premissas de sua doutrina, ou de agir segundo interesses do laico do Estado. Devemos lembrar que uma religião "se infiltra nos poros da vida cotidiana" (HABERMAS, 2005: 144), de tal sorte que "opõe-se, segundo o teor da objeção, a qualquer tipo de transposição de convicções políticas enraizadas na religião para outra base cognitiva." (Ibidem) Em outras palavras, se analisamos uma religião a partir de seus fundamentos, e se apelamos a eles para entender a via de ação escolhida por um de seus adeptos, nela encontramos uma forte intransigência que não permite ao 
fiel fazer concessões a outras formas de legitimação e, portanto, nem mesmo se presta ao debate. O mesmo se dá entre religiões de orientações diferentes, que não se dispõem a entrar em acordo entre si e, eventualmente, chegam a ser irreconciliáveis em pontos vitais de suas doutrinas, criando um clima de animosidade que cinde a sociedade.

\begin{abstract}
Não é possível aplainar cognitivamente a concorrência entre doutrinas religiosas e visões de mundo [...] Tão logo, porém, tais dissonâncias cognitivas se infiltram nas bases da convivência dos cidadãos, regulada normativamente, a comunidade política se segmenta em comunidades religiosas e comunidades que adotam visões de mundo irreconciliáveis [...] (HABERMAS, 2005: 153-4).
\end{abstract}

Habermas não refuta a legitimidade da interferência da religião na política. Sua participação é válida na medida em que um regime democrático é composto de elementos diversos e deve dar vez e voz a todos eles. Contudo, visto que a religião e a razão (científica) constituem pólos opostos - e não raras vezes mutuamente excludentes - de configuração de visões de mundo, além de compartilharem tendências "totalizantes", ou seja, a pretensão de serem, cada uma, a única cosmovisão plausível e principalmente por se colocarem como mutuamente indisponíveis para diálogo com seu lado oposto, Habermas se vê em posição de desenvolver "uma concepção [do papel político da religião] cuja finalidade principal consiste em mediar entre os dois lados discutindo as propostas revisionistas que atingem fundamentos da autocompreensão liberal." (HABERMAS, 2005: 135) Tratase aqui de aplicar a noção de razão comunicativa como meio de estabelecer um diálogo possível entre as partes interessadas. Para tanto, o filósofo deve analisar os pressupostos cognitivos necessários aos cidadãos - laicos ou religiosos - para que estes possam efetivamente cumprir o papel de civilidade que lhes é requerido. Tal análise tem de levar em conta, de um lado, as bases pré-políticas de um Estado democrático e, de outro, deve insistir 
na tolerância como item indispensável para a convivência numa sociedade pluralista.

Podemos aqui partir do conceito de cooriginalidade, segundo o qual podemos conceber que os cidadãos sejam a um só tempo autores e destinatários das leis que seguem. Ora, é preciso lembrar que os cidadãos religiosos (em Estados seculares) "mesmo quando aduzem razões religiosas estão assumindo posição em sentido político" (HABERMAS, 2005: 147), o que significa que, de antemão, eles tomam como legítimo o Estado ao qual estão submetidos. Em alguns casos, percebemos como a história constitucional se liga à própria determinação da religião, que se desenvolve enquanto tal sob a proteção do Estado laico. O melhor exemplo disso é o dos Estados Unidos.

O poder do Estado, cuja postura quanto a visões de mundo era neutra, não tinha, em primeira linha, o sentido negativo de proteger os cidadãos contra imposições oriundas da consciência ou da fé. Ele deveria, ao invés disso, garantir para os colonos que tinham dado as costas à velha Europa a liberdade positiva de colocar em prática, sem restrições, sua respectiva religião. Por isso, até hoje em dia, qualquer uma das partes envolvidas numa discussão sobre o papel político da religião pode reiterar sua lealdade para com a constituição. (HABERMAS, 2005: 134).

O pressuposto cognitivo básico - e isso vale tanto para cidadãos religiosos quanto para seculares - é o de que haja respeito recíproco

como membros de sua respectiva comunidade política, dotados de iguais direitos, apesar de seu dissenso em questões envolvendo convicções religiosas e visões de mundo; sobre esta base de uma solidariedade de cidadãos do Estado, eles devem procurar, quando se trata de questões disputadas, um entendimento mútuo motivado racionalmente, ou seja, eles são obrigados 
a apresentar, uns aos outros, bons argumentos.

(HABERMAS, 2005: 137).

Há duas questões a ressaltar aqui. A primeira é a de que o pressuposto cognitivo implica presumir no outro "racionabilidade": "Tal potencial [de intuições morais universais] faz do discurso religioso [...] um candidato sério a possíveis conteúdos de verdade." (HABERMAS, 2005: 148-9) A segunda, a existência de uma aspiração de legitimidade em suas motivações: "uma vez que todos desejam os mesmos tipos de bens compartilháveis, podem [os cidadãos de orientação religiosa] assumir compromissos [com um Estado laico]." (HABERMAS, 2005: 153)

Sem o laço unificador de uma solidariedade [...] os cidadãos não conseguem entender-se como participantes, com iguais direitos, de uma prática comum que possibilita a formação da opinião e da vontade na qual uns devem aos outros argumentos para seus posicionamentos políticos. (HABERMAS, 2005: 154).

É notável a insistência de Habermas na necessidade de que os conflitos sejam solucionados por meio da argumentação. É por isso que é central em sua proposta a noção de tradutibilidade, que aparece como uma condição para a participação de religiosos na esfera pública. "Só valem como legítimas", afirma Habermas,

as decisões que puderem ser tomadas à luz de argumentos acessíveis em geral, isto é, que são imparciais tanto para cidadãos religiosos como para não-religiosos, como também para cidadãos de orientações de fé distintas. O exercício de um poder que não consegue justificar-se de modo imparcial é ilegítimo porque, nesse caso, um partido estaria impondo sua vontade ao outro. Cidadãos devem apresentar, uns aos outros, argumentos porque 
somente assim o poder político perde o seu caráter eminentemente repressivo. (HABERMAS, 2005: 139)

A acessibilidade ao público em geral (laicos ou de outras denominações religiosas) é condição para que as demandas religiosas façam parte das agendas institucionais, de modo a efetivar a influência que pretendem ter no processo político. Para tanto, a autopercepção religiosa precisa processar a dissonância cognitiva que conta contra ela (assimetricamente, já que não pesam para cidadãos seculares em geral). Esquematicamente, Habermas pontua três mudanças de enfoque que as religiões devem adotar para pôr fim à dissonância: 1. Aceitar o fato do pluralismo religioso e refletir sobre si mesma a partir dele; 2 . Aceitar os saberes seculares e o monopólio de especialistas a partir da determinação da relação destes com seus dogmas e; 3. Aceitar a primazia dos argumentos seculares na esfera política, mesmo nos campos do direito e da moral. Podemos reduzir toda a questão a um denominador comum: uma democracia efetiva é formada por múltiplos discursos e o discurso moral (que aparentemente é o mais comum às religiões) é apenas um deles. Insistir nesses pontos é insistir para que a religião mantenha-se em constante reflexão, ou supô-la. É nesse sentido que Habermas fala em processos de aprendizagem que se configuram quando da observância desses enfoques. Vale frisar que o mesmo é válido para a razão secular em relação aos conteúdos advindos da religião. "A compreensão perspicaz de cidadãos seculares, de que é preciso viver numa sociedade pós-secular sintonizada epistemicamente com a sobrevivência de comunidades religiosas", diz Habermas,

depende de uma mudança de mentalidade cujas pretensões não são menores do que as de uma consciência religiosa que precisa adaptar-se aos desafios do entorno que se seculariza cada vez mais [...] Sem tal pressuposição cognitiva, não se pode exigir nenhuma expectativa normativa de um uso público da razão [...] Tal pressuposição significa que o etos democrático de cidadãos do Estado só pode 
ser imputado simetricamente a todos os cidadãos se estes, tanto os seculares como os religiosos, passarem por processos de aprendizagem complementares. (HABERMAS, 2005: 158).

Aqui, de uma única tacada Habermas se põe na esteira da compreensão do esclarecimento de Kant, que o vincula a um processo que se dá pelo uso público da razão e reposiciona o papel da tolerância, tratado pelo mesmo iluminista, mas que aqui toma a forma da convivência numa sociedade plural.

Tolerância mútua exige, por isso, das próprias comunidades seculares 'fortes', o engate cognitivo de seu etos interno à moral da humanidade, a qual prevalece no entorno social e político. [...] O empurrão para a reflexão que as sociedades dotadas de uma pluralidade de visões de mundo esperam da consciência religiosa constitui, por seu turno, um protótipo para a configuração mental de sociedades multiculturais. Portanto, um multiculturalismo bementendido não constitui apenas uma via de mão única para a autoafirmação cultural de grupos que possuem identidade própria. Por outro lado, a coexistência, com igualdade de direitos, de diferentes formas de vida não pode levar a uma segmentação. Ela exige uma integração dos cidadãos do Estado-e o reconhecimento recíproco de suas pertenças a grupos subculturais no quadro de uma cultura política compartilhada. A autorização para formar características culturais típicas exige, como condição preliminar, que os 'cidadãos da sociedade' se entendam - para além de qualquer tipo de fronteira subcultural - como 'cidadãos do Estado' de uma mesma comunidade política. (HABERMAS, 2005: 300). 


\section{Diversidade e tolerância}

Por fim, cabe juntar as perspectivas de Cassirer e Habermas a partir do que aqui foi exposto. A fragmentação da racionalidade que marca o fim da modernidade teve como um de seus frutos o ressurgimento do mito no seio da sociedade e esse processo culminou no surgimento do regime político mais nefasto de que se tem notícia na história recente justamente no interior de um sistema democrático, o de Weimar. A intolerância e a comunicabilidade se tornaram impraticáveis e o próprio regime democrático - talvez por sua própria incapacidade de diálogo - foi aniquilado sem aparente resistência. A exposição histórica de Cassirer sobre os mitos políticos é também a história do distanciamento crítico dos elementos que estavam por sob o aparente progresso político. Isso nos põe a repensar a pretensão de "eternidade" de nossas aquisições culturais (ciência, artes, religião etc.). "Devemos sempre estar preparados para convulsões violentas que podem abalar o nosso mundo cultural e a nossa ordem social nas suas fundações", diz Cassirer (CASSIRER, 1946: 342). E acrescenta:

Os poderes do mito foram desafiados e vencidos por forças superiores. Enquanto essas forças intelectuais, éticas e artísticas estão em pleno vigor, o mito está dominado e subjugado. Mas, apenas elas começam a afrouxar, o caos volta outra vez. O pensamento mítico ergue-se de novo e infecta toda a vida cultural e social do homem. (CASSIRER, 1946: 343)

A advertência de Cassirer nos parece plenamente atual. Quase um século depois do fim do regime nazista, presenciamos um aumento significativo de tendências fascistas mundo afora, além da assim chamada "guerra contra o terror". Muitas dessas tendências são de matiz religioso e outras tantas, advindas de Estados laicos, se apoiam numa moralidade hipostasiada tipicamente mítico-religiosa que vem fazendo crescer a olhos nus o clima de intolerância. Tal intolerância, ainda, parece ser dirigida 
a grupos isolados "eleitos" como plenamente desarrazoados e, destarte, grupos inaptos ao diálogo e ao entendimento pacífico - os muçulmanos, por exemplo. Em seu lugar, a alternativa propalada é a da intervenção violenta contra tais grupos, como se estes fossem a causa única dos males da sociedade - convertidos, miticamente, em bodes expiatórios - tal como o nazismo fez com todos os nãoarianos.

A reação de tais grupos, quando são organizados, não é menos intolerante, posto que generalizam sua revolta contra um abstrato "ocidente" e identificam como problema, por vezes, o Estado laico e a própria democracia. Uma vez que a matriz religiosa esteja mais presente, o "combate" contra as "forças inimigas" ganha ares de dever religioso e, como tal, faz-se inquestionável novamente, não há diálogo; a razão (comunicativa) não é chamada a participar, muito embora seja aqui que ela se faça indispensável. O risco óbvio é de um recrudescimento da fragmentação social e de um esfacelamento da esfera pública que colocaria novamente em xeque o projeto de uma sociedade cosmopolita.

Habermas é contundente em mostrar como o processo de globalização não será efetivado simplesmente por meio do estabelecimento de uma comunidade política de direito. Os processos de formação da vontade são imprescindíveis tanto quanto dependentes do próprio exercício democrático, balizado pelo agir comunicativo. É preciso ter sempre em mente que o exercício comunicativo não se finda, tanto quanto não se finda a disputa entre as formas simbólicas. A dialética da cultura é sempiterna na mesma medida em que o agir comunicativo demanda a possibilidade de problematização irrestrita.

O exercício democrático é a convivência com o diverso, ao qual nos unimos por meio de um sentimento de igualdade (enquanto seres humanos), de reconhecimento, que, em última instância, funda o direito e a ética. Estes pontos, entretanto, estão sempre sob a ameaça do arcabouço mítico - este que tende a ressurgir sempre que a sociedade encontra um problema para o qual não vislumbra solução racional. Nesse sentido, as crises econômicas que vivemos desde 2008 são fatores que contribuem 
significativamente para o aumento das tendências nacionalistas de matiz fascista, que eventualmente extrapolam para discriminações de ordem étnica e racial. De todo modo, são ocasiões que, como tal, fazem sobressair as diferenças regionais em detrimento dos fatores de integração que possibilitariam a manutenção do diálogo e da compreensão. Para todas elas, a filosofia e as ciências sociais precisam manter a vigilância, pois é a elas que cabe neutralizar os mitos políticos e promover a tolerância, condições de possibilidade da democracia efetiva.

\section{Bibliografia}

CASSIRER, E. (1944) Ensaio sobre o homem. São Paulo: Martins Fontes, 2000.

. (1923) Filosofia das formas simbólicas vol. I - Linguagem. São Paulo: Martins fontes, 2001.

- (1925) Filosofia das formas simbólicas vol. II -O pensamento Mítico. São Paulo: Martins fontes, 2004.

. (1946) O mito do Estado. São Paulo: Códex, 2003.

. (1923b) Der Begriff der symbolischen Form im Aufbau der Geisteswissenschaft. Ernst Cassirers Gesammelte Werke. Hamburg: Felix Meiner, 1998.

. (1910) Substanzbegriff und Funktionsbegriff. Ernst Cassirers Gesammelte Werke. Hamburg: Felix Meiner, 1998.

HABERMAS, J. (1985) O discurso filosófico da modernidade. São Paulo: Martins Fontes, 2000. . (2005) Entre naturalismo e religião. Rio de Janeiro: Edições Tempo Brasileiro, 2007.

Recebido em 09/09/13.

Aprovado em 13/05/14. 
